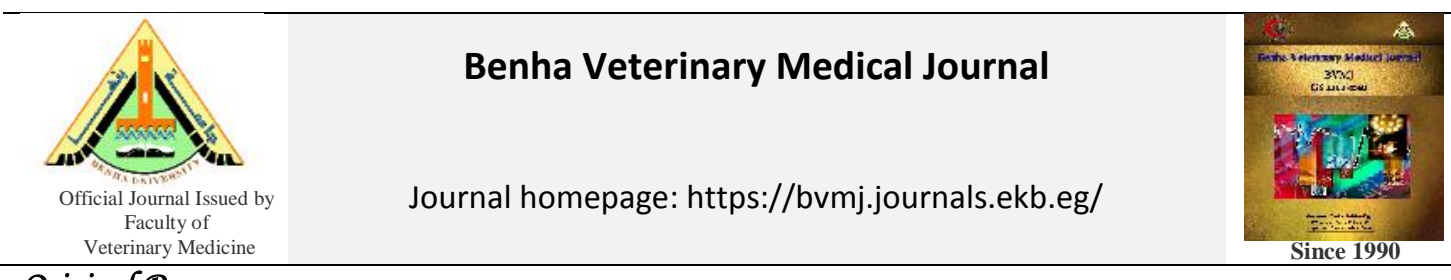

Original Paper

\title{
Antibacterial efficiency of apple cider vinegar and pomegranate molasses on meat meals served at a university student hostel
}

Amani M. Salem ${ }^{1}$, Marionette Nassif and Bashayer Mohammed ${ }^{3}$

${ }^{1}$ Department of Food Hygiene and Control, Faculty of Veterinary Medicine, Benha University,, Egypt

${ }^{2}$ Animal Health Research Institute., Department of Food Hygiene., Benha branch.

${ }^{3}$ Veterinarian in Shoubra student hostel, Benha University, Egypt.

ARTICLE INFO

Keywords

Antibacterial

Apple Cider Vinegar

Enterobacteriacae

Pomegranate Molasses

S. aureus

Received 06/05/2020

Accepted 27/05/2020

Available On-Line

08/09/2020

\begin{abstract}
Antibacterial effect of pomegranate molasses (PM) and apple cider vinegar (ACV) on chicken meat and beef samples before and after cooking was investigated in this study. The samples were separated into six groups as control (untreated), and treated ones with 5\% PM, $3 \% \mathrm{PM}, 4 \% \mathrm{ACV}, 2 \% \mathrm{ACV}$ and mix between two concentrations (2\% ACV \& 3\% PM). A total of 24 samples of chicken and meat were collected from a university hostel. The samples were marinated by the previous concentrations of PM and ACV for 2 hours. Half of them were cooked, then each raw and cooked samples were kept in a separate plastic bag and transferred directly to the laboratory in an insulating refrigerated container under complete aseptic conditions (the experiment was repeated three times).The samples were examined to determine APC, Enterobacteriacae, coliform and the incidence of Salmonella, E. coli and Staph. aureus. The best results were obtained by the treated groups by the mix of $2 \%$ ACV\& $3 \% \mathrm{PM}$ and 5\% PM as compared with the other treated groups.
\end{abstract}

\section{INTRODUCTION}

Meat constitutes the center of the meal served at most university student hostels because of its palatability and highly nutritional value by protein and vitamins. For this high nutritional value, it offers a highly favorable environment for the growth of pathogenic microorganisms. (Sharp and Walker, 2003).

Poor personal hygiene, improper cleaning of storage and preparation areas and unclean utensils are considered the main causes of contamination of raw and cooked foods. Mishandling of these foods allows bacteria to grow. Also, food handlers should never leave food out of refrigeration for longer than two hours. If the temperature above $32^{\circ} \mathrm{C}$, food should not be left out more than one hour to avoid food poisoning (FSIS, 2008).

Due to the hazards of food poisoning and food borne illness, incorporation of natural additives to meat became a necessary need to control these dangers; natural components are preferred due to their safety in a comparison with synthetic ones.

Pomegranate has antibacterial activity against food and waterborne pathogenic bacteria including S. Typhi (Rani and Khullar, 2004). Further, apple vinegar has antimicrobial, antioxidant, anti-diabetic, anti-inflammatory, antihypertensive, immune-stimulatory and anticancer effects (Kalaba et al., 2019).

Total aerobic plate count (APC) is used as an indicator of bacterial population on a sample. It is not a measure of the entire bacterial population, but as its name implies, it is a generic test for microorganisms that grow aerobically at mesospheric temperature, but doesn't differentiate the types of bacteria (APHA, 2001). It can be routinely used as indicator of improper hygiene during processing and bad storage conditions, which can lead to a proliferation of pathogens and toxin production (Zeweifel et al., 2005). Also, Enterobacteriaceae have an epidemiological interest as some of its members are pathogenic.

Staphylococcal intoxication outbreaks occur mostly due to post-preparation contamination by food handlers, utensils and surfaces (ICMSF, 1997).

Attention to health issues of the personnel of any institute is one of the most crucial responsibilities of the health authorities. Since consumption of healthy food is one of the significant factors affecting the health, such studies are extremely important and will be helpful in supervision and control of quality of food stuffs, especially in a university center. Therefore, this study was to investigate the antibacterial effect of pomegranate molasses and apple cider vinegar in meat meals served at a university hostel.

\section{MATERIAL AND METHODS}

2.1. Preparation of used additives:

Commercially available Apple cider vinegar (ACV) and Pomegranate molasses (PM) were obtained from a local market in Shebein El Qanatir city,Qalioubia Governorate and prepared to reach to concentration (2\%) ACV, (4\%) $\mathrm{ACV},(3 \%) \mathrm{PM}$ and (5\%)PM .

\subsection{Collection of samples:}

Beef and chicken samples were divided into six groups. The samples were subjected to the following treatments:

* Corresponding author: Amani M. Salem, Food Control Dept., Faculty of Veterinary Medicine, Benha University, Egypt. 
control (untreated) and treated samples, the treated ones were marinated with pomegranate molasses $5 \%$, pomegranate molasses $3 \%$, apple cider vinegar $2 \%$, apple cider vinegar $4 \%$ and mix between $2 \%$ ACV \& $3 \%$ PM for 2 hours, half of samples were cooked and both raw and cooked samples were then kept in a separate plastic bags and transferred directly to the laboratory of Food Hygiene in an ice box under complete aseptic conditions without undue delay to be subjected to the following examination.

\subsection{Sensory evaluation:}

Sensory traits were evaluated according to Meilgaard et al. (1999).

\subsection{Preparation of samples:}

The samples were prepared according to the technique recommended by APHA (2001) as follow: Accurately , 25 grams of examined samples were transferred to a sterile stomacher aseptically bag and then homogenized with 225 $\mathrm{ml}$ of $0.1 \%$ sterile peptone water for $1-2$ min to give an initial dilution of $1 / 10$. The next dilution was done by transferring $1 \mathrm{ml}$ from the original to a tube containing $9 \mathrm{ml}$ of sterile peptone water $(1 \%)$ and then mixed thoroughly by using vortex for 5-10 seconds; the next dilutions were done by the same criteria. These dilutions from untreated and treated groups were subjected to:

2.2.1. Aerobic Plate Count (APHA, 2001)

2.2.2. Enterobacteriaceae Count (ISO, 2004).

2.2.3. Coliform count (ISO, 2004).

2.2.4. Isolation and identification of E. coli (ISO 2001)

2.2.5. Isolation and Identification of Salmonella (ISO, 2002).

2.2.6. Isolation and Identification of Staphylococcus aureus (ICMSF, 1996).

\subsection{Statistical Analysis:}

The obtained results were statistically analyzed by application of Analysis of Variance (ANOVA) test according to Feldman et al. (2003).

\section{RESULTS}

Results in Table (1) illustrated the effects of different concentrations of ACV and PM on acceptability of tested groups. Sensory attributes of different treated chicken meat and beef samples were mostly improved with all treatments when compared with control.

Table 1 Effect of certain additives on sensory traits of the examined samples of chicken and meat meals $(n=24)$.

\begin{tabular}{lcccccc}
\hline Samples & Control & PM & PM & ACV & ACV & PM3\%+ \\
& & $3 \%$ & $5 \%$ & $2 \%$ & $4 \%$ & ACV2\% \\
\hline $\begin{array}{l}\text { Chicken } \\
\text { (before cooking) }\end{array}$ & 8 & 9 & 9 & 8 & 8 & 8 \\
$\begin{array}{l}\text { Chicken } \\
\text { (after cooking) }\end{array}$ & 8 & 9 & 9 & 9 & 9 & 9 \\
$\begin{array}{l}\text { Beef } \\
\text { (before cooking) }\end{array}$ & 8 & 9 & 9 & 9 & 9 & 9 \\
$\begin{array}{l}\text { Beef } \\
\text { (after cooking) }\end{array}$ & 8 & 9 & 9 & 9 & 9 & 9 \\
\hline $\begin{array}{l}\text { (9) Highly preferred, (8) lots preferred, (7) fairly preferred, (6) slightly preferred, (5) } \\
\text { similar, (4) slightly not preferred. }\end{array}$ &
\end{tabular}

It is evident from the results recorded in Table (2) that the mean values of APC count (cfug) in the examined group samples of control, ACV (2\%), ACV (4\%), PM (3\%), $\mathrm{PM}(5 \%)$ and $\mathrm{Mix}(2 \% \mathrm{ACV} \& 3 \% \quad \mathrm{PM})$ were $3 \times 10^{5} \pm 0.01 \times 10^{5}, 2 \times 10^{5} \pm 0.02 \times 10^{3}, 2 \times 10^{4} \pm 0.02 \times 10^{2}, 2 \times 10^{5}$ $\pm 0.01 \times 10^{3}, 2 \times 10^{4} \pm 0.01 \times 10^{2}$ and $1.5 \times 10^{4} \pm 0.01 \times 10^{2}$, respectively in chicken before cooking, while were $1.2 \times 10^{4} \pm 0.03 \times 10^{2}, \quad 7 \times 10^{3} \pm 0.02 \times 10^{2}, \quad 6 \times 10^{3} \pm 0.01 \times 10^{2}$,
$9 \times 10^{3} \pm 0.01 \times 10^{2}, \quad 4 \times 10^{3} \pm 0.01 \times 10^{2}$ and $3 \times 10^{3} \pm 0.01 \times 10^{3}$, respectively in chicken after cooking. Moreover, they were $2.8 \times 10^{6} \pm 0.01 \times 10^{5}$ and $2.4 \times 10^{5} \pm 0.02 \times 10^{4}, \quad 1.8$ $\times 10^{4} \pm 0.01 \times 10^{2}, 2 \times 10^{5} \pm 0.01 \times 10^{3}, 2 \times 10^{4} \pm 0.01 \times 10^{2}$ and 1.5 $\times 10^{5} \pm 0.01 \times 10^{2}$, respectively in beef before cooking. Finally, they were $1.2 \times 10^{4} \pm 0.01 \times 10^{4}, 7 \times 10^{3} \pm 0.02 \times 10^{3}$, $5.4 \times 10^{3} \pm 0.01 \times 10^{3}, \quad 9 \times 10^{3} \pm 0.01 \times 10^{3}, \quad 3 \times 10^{3} \pm 0.01 \times 10^{3}$ and $2 \times 10^{3} \pm 0.01 \times 10^{3}$, respectively in beef after cooking. There is a significant difference of APC between samples $(\mathrm{P} \leq 0.05)$. Therefore, the reduction $\%$ of treated groups based on their APC mean values in treated groups by ACV (2\%), ACV (4\%), PM (3\%), PM (5\%) and Mix (2\%ACV\&3\%PM) were $41.66 \%, 50 \%, 25 \%, 66.66 \%$ and $75 \%$, respectively in chicken after cooking, while were $41.66 \%, 55 \%, 25 \%, 75 \%$ and $83.33 \%$, respectively in beef meat after cooking.

Also, results in Table (3) showed the mean values of Enterobacteriacae count (cfu/g) in the examined samples of control , ACV (2\%), ACV (4\%), PM (3\%), PM (5\%) and $\mathrm{Mix}(2 \% \mathrm{ACV} \& 3 \% \mathrm{PM})$ were $8.9 \times 10 \pm 0.02 \times 10$, $6.2 \times 10 \pm 0.01 \times 10, \quad 5.4 \times 10 \pm 0.02 \times 10,6.5 \times 10 \pm 0.01 \times 10$, $5.5 \times 10 \pm 0.01 \times 10$ and $4.1 \times 10 \pm 0.02 \times 10$, respectively in chicken before cooking, while in chicken after cooking were $7.5 \times 10 \pm 0.02 \times 10,6 \times 10 \pm 0.02 \times 10,4.7 \times 10 \pm 0.01 \times 10$, $6.1 \times 10 \pm 0.01 \times 10,5.4 \times 10 \pm 0.01 \times 10$ and $2.6 \times 10 \pm 0.02 \times 10$, respectively. The results in beef before cookingwere $8.5 \times 10 \pm 0.01 \times 10,6.2 \times 10 \pm 0.02 \times 10,4.7 \times 10 \pm 0.0$ $1 \times 10, \quad 6.5 \times 10 \pm 0.01 \times 10, \quad 5.5 \times 10 \pm 0.02 \times 10 \quad$ and $4.1 \times 10 \pm 0.02 \times 10$, respectively. Moreover, in beef after cooking were $6.2 \times 10 \pm 0.01 \times 10, \quad 5 \times 10 \pm 0.02 \times 10$, $3.7 \times 10 \pm 0.01 \times 10, \quad 5.1 \times 10 \pm 0.01 \times 10,4.4 \times 10 \pm 0.02 \times 10$ and $2 \times 10 \pm 0.01 \times 10$, respectively.

Table (3) also showed the reduction $\%$ of treated groups based on their Enterobacteriacae mean values in treated groups by ACV (2\%), ACV (4\%), PM (3\%), PM (5\%) and Mix (2\%ACV\&3\%PM) which were $20 \%, 37.33 \%$, $18.66 \%, 28 \%$ and $65.33 \%$, respectively in chicken after cooking, while were $19.4 \%, 40.3 \%, 18 \%, 29 \%$ and $67.7 \%$, respectively in beef after cooking.

There is a significant difference between different treatments in beef samples ( $\mathrm{P} \leq 0.05)$, while there is no significant difference in chicken samples ( $\mathrm{P} \quad 0.05$ ).

Table (4) indicated the results of Coliform count (cfu/g) in the examined samples of control, ACV (2\%), ACV (4\%), $\mathrm{PM}(3 \%), \quad \mathrm{PM}(5 \%)$ and Mix (2\%ACV\&3\%PM) 9.5 $\times 10 \pm 0.01 \times 10, \quad 6.9 \times 10 \pm 0.01 \times 10, \quad 4.3 \times 10 \pm 0.02 \times 10$, $7.5 \times 10 \pm 0.01 \times 10, \quad 5.2 \times 10 \pm 0.01 \times 10$ and $2.7 \times 10 \pm 0.01 \times 10$, respectively in chicken before cooking. While in chicken after cooking were $6 \times 10 \pm 0.01 \times 10, \quad 5.2 \times 10 \pm 0.01 \times 10$, $4.3 \times 10 \pm 0.02 \times 10, \quad 5.2 \times 10 \pm 0.01 \times 10, \quad 4.2 \times 10 \pm 0.01 \times 10$ and $2.7 \times 10 \pm 0.01 \times 10$, respectively. The results in beef before cooking were $1 \times 10^{2} \pm \pm 0.01 \times 10^{2}, \quad 6.2 \times 10 \pm 0.01 \times 10^{2}$, $3.3 \times 10 \pm 0.01 \times 10^{2}, 8.1 \times 10 \pm 0.02 \times 10,5.2 \times 10 \pm 0.01 \times 10^{2}$ and $2.6 \times 10 \pm 0.02 \times 10$, respectively. Therefore, in beef after cooking were $5.7 \times 10 \pm 0.01 \times 10, \quad 4.2 \times 10 \pm 0.01 \times 10$, $3.4 \times 10 \pm 0.01 \times 10, \quad 4.2 \times 10 \pm 0.02 \times 10, \quad 3.2 \times 10 \pm 0.01 \times 10$ and $2.6 \times 10 \pm 0.01 \times 10$, respectively.

The reduction $\%$ of treated groups based on their Coliform mean values in treated groups by ACV (2\%), ACV (4\%), $\mathrm{PM}(3 \%), \quad \mathrm{PM}(5 \%)$ and Mix (2\% ACV\&3\% PM) were $13.33 \%, 28.33 \%, 12.9 \%, 30 \%$ and $55 \%$, respectively in chicken after cooking, while in beef after cooking were $26.3 \%, 40.4 \%, 26.3 \%, 43.9 \%$ and $54.4 \%$, respectively.

Table (5) indicated the effect of treatments on incidence of Staph. aureus in the treated groups by ACV (2\%), ACV (4\%), PM (3\%), PM (5\%) and Mix (2\%ACV\&3\%PM 
which were $9.9 \times 10 \pm 0.01 \times 10,9.8 \times 10 \pm 0.02 \times 10, \quad 8.7 \times 10$ $\pm 0.01 \times 10, \quad 5.7 \times 10 \pm 0.02 \times 10, \quad 4.2 \times 10 \pm 0.01 \times 10 \quad$ and $3.7 \times 10 \pm 0.02 \times 10$, respectively in chicken before cooking. While in chicken after cooking were $9.9 \times 10 \pm 0.01 \times 10,8.7$ $\times 10 \pm 0.01 \times 10, \quad 8.7 \quad \times 10 \pm 0.02 \times 10 \quad, 9.3 \times 10 \pm 0.02 \times 10$, $3.1 \times 10 \pm 0.01 \times 10$ and $2.8 \times 10 \pm 0.02 \times 10$, respectively. Moreover were $8.6 \times 10 \pm 0.02 \times 10, \quad 9.4 \times 10 \pm 0.02 \times 10$, $8 \times 10 \pm 0.02 \times 10, \quad 8.3 \times 10 \pm 0.01 \times 10, \quad 6.2 \times 10 \pm 0.01 \times 10$, $4.2 \times 10 \pm 0.01 \times 10$, respectively in beef before cooking. Finally, in beef meals after cooking were $8.6 \times 10 \pm 0.02 \times 10$,
$7.7 \times 10 \quad \pm 0.02 \times 10, \quad 7.7 \times 10 \pm 0.02 \times 10, \quad 8.6 \times 10 \pm 0.01 \times 10$, $4.2 \times 10 \pm 0.01 \times 10,3.2 \times 10 \pm 0.01 \times 10$, respectively.

The same table showed the reduction \% in Staph. aureus incidence in treated groups by ACV (2\%), ACV (4\%), PM (3\%), PM (5\%) and Mix (2\%ACV\&3\%PM which were $12 \%, 12 \%, 6 \%, 68.7 \%$ and $71.7 \%$, respectively in chicken after cooking, while were $10.5 \%, 10.5 \%,-, 51 \%$ and $62.8 \%$, respectively in beef after cooking.

It is evident from the previous results that there is no significant difference of Staph. aureus count between samples ( $\mathrm{P}$ 0.05).

Table 2 Effect of certain additives on Aerobic plate count (APC) of served chicken and meat meals $(\mathrm{n}=24)$.

\begin{tabular}{|c|c|c|c|c|c|c|}
\hline Additives & $\begin{array}{l}\text { Chicken } \\
\text { (before cooking) }\end{array}$ & $\begin{array}{l}\text { Chicken } \\
\text { (after cooking) }\end{array}$ & Red.\% & $\begin{array}{l}\text { Beef } \\
\text { (before cooking) }\end{array}$ & $\begin{array}{l}\text { Beef } \\
\text { (after cooking) }\end{array}$ & Red.\% \\
\hline Control & $3^{\mathrm{a}} \times 10^{5} \pm 0.01 \times 10^{5}$ & $1.2^{\mathrm{d}} \times 10^{4} \pm 0.03 \times 10^{4}$ & 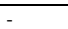 & $2.8^{\mathrm{a}} \times 10^{6} \pm 0.01 \times 10^{5}$ & $1.2^{\mathrm{d}} \times 10^{4} \pm 0.01 \times 10^{4}$ & - \\
\hline $\operatorname{ACV}(2 \%)$ & $2^{\mathrm{b}} \times 10^{5} \pm 0.02 \times 10^{3}$ & $7^{\mathrm{d}} \times 10^{3} \pm 0.02 \times 10^{3}$ & 41.66 & $2.4^{b} \times 10^{5} \pm 0.02 \times 10^{4}$ & $7^{\mathrm{d}} \times 10^{3} \pm 0.02 \times 10^{3}$ & 41.66 \\
\hline $\mathrm{ACV}(4 \%)$ & $2^{\mathrm{d}} \times 10^{4} \pm 0.02 \times 10^{2}$ & $6^{\mathrm{d}} \times 10^{3} \pm 0.01 \times 10^{3}$ & 50 & $1.8^{\mathrm{d}} \times 10^{4} \pm 0.01 \times 10^{2}$ & $5.4^{\mathrm{d}} \times 10^{3} \pm 0.01 \times 10^{3}$ & 55 \\
\hline PM $(3 \%)$ & $2^{c} \times 10^{5} \pm 0.01 \times 10^{3}$ & $9^{\mathrm{d}} \times 10^{3} \pm 0.01 \times 10^{4}$ & $\begin{array}{l}30 \\
25\end{array}$ & $2^{\mathrm{c}} \times 10^{5} \pm 0.01 \times 10^{3}$ & $9^{\mathrm{d}} \times 10^{3} \pm 0.01 \times 10^{3}$ & 25 \\
\hline PM $(5 \%)$ & $2^{\mathrm{d}} \times 10^{4} \pm 0.01 \times 10^{2}$ & $4^{\mathrm{d}} \times 10^{3} \pm 0.01 \times 10^{3}$ & 66.66 & $2^{\mathrm{d}} \times 10^{4} \pm 0.01 \times 10^{2}$ & $3^{\mathrm{d}} \times 10^{3} \pm 0.01 \times 10^{3}$ & 75 \\
\hline $\operatorname{Mix}(2 \%$ ACV \&3\%PM) & $1.5^{\mathrm{d}} \times 10^{4} \pm 0.01 \times 10^{2}$ & $3^{\mathrm{d}} \times 10^{3} \pm 0.01 \times 10^{3}$ & 75 & $1.5^{\mathrm{d}} \times 10^{4} \pm 0.01 \times 10^{2}$ & $2^{\mathrm{d}} \times 10^{3} \pm 0.01 \times 10^{3}$ & 83.33 \\
\hline
\end{tabular}

Red. \%= reduction percentage. Different letters superscript showed significance differences $(\mathrm{p} \triangle 0.05)$.

Table 3 Effect of certain additives on mean value of Enterobacteriacae count of served chicken and meat meals $(\mathrm{n}=24)$

\begin{tabular}{|c|c|c|c|c|c|c|}
\hline Additives & $\begin{array}{l}\text { Chicken } \\
\text { (before cooking) }\end{array}$ & $\begin{array}{l}\text { Chicken } \\
\text { (after cooking) }\end{array}$ & Red. $\%$ & $\begin{array}{l}\text { Beef } \\
\text { (before cooking) }\end{array}$ & $\begin{array}{l}\text { Beef } \\
\text { (after cooking) }\end{array}$ & Red.\% \\
\hline Control & $8.9^{\mathrm{a}} \times 10 \pm 0.02 \times 10$ & $7.5^{\mathrm{b}} \times 10 \pm 0.02 \times 10$ & - & $8.5^{\mathrm{a}} \times 10 \pm 0.01 \times 10$ & $6.2^{\mathrm{bc}} \times 10 \pm 0.01 \times 10$ & - \\
\hline $\operatorname{ACV}(2 \%)$ & $6.2^{\mathrm{c}} \times 10 \pm 0.01 \times 10$ & $6^{c} \times 10 \pm 0.02 \times 10$ & 20 & $6.2^{\mathrm{bc}} \times 10 \pm 0.02 \times 10$ & $5^{\mathrm{def}} \times 10 \pm 0.02 \times 10$ & 19.4 \\
\hline $\operatorname{ACV}(4 \%)$ & $5.4^{\mathrm{cd}} \times 10 \pm 0.02 \times 10$ & $4.7^{\mathrm{cd}} \times 10 \pm 0.01 \times 10$ & 37.33 & $4.7^{\mathrm{cd}} \times 10 \pm 0.01 \times 10$ & $3.7^{\mathrm{g}} \times 10 \pm 0.01 \times 10$ & 40.3 \\
\hline PM (3\%) & $6.5^{\mathrm{c}} \times 10 \pm 0.01 \times 10$ & $6.1^{c} \times 10 \pm 0.01 \times 10$ & 18.66 & $6.5^{\mathrm{b}} \times 10 \pm 0.01 \times 10$ & $5.1^{\mathrm{def}} \times 10 \pm 0.01 \times 10$ & 18 \\
\hline $\mathrm{PM}(5 \%)$ & $5.5^{\mathrm{cd}} \times 10 \pm 0.01 \times 10$ & $5.4^{\mathrm{cd}} \times 10 \pm 0.01 \times 10$ & 28 & $5.5^{\mathrm{bcd}} \times 10 \pm 0.02 \times 10$ & $4.4^{\mathrm{efg}} \times 10 \pm 0.02 \times 10$ & 29 \\
\hline $\operatorname{Mix}(2 \% \mathrm{ACV} \& 3 \% \mathrm{PM})$ & $4.1^{\mathrm{e}} \times 10 \pm 0.02 \times 10$ & $2.6^{\mathrm{f}} \times 10 \pm 0.02 \times 10$ & 65.33 & $4.1^{\mathrm{fg}} \times 10 \pm 0.02 \times 10$ & $2^{\mathrm{h}} \times 10 \pm 0.01 \times 10$ & 67.7 \\
\hline
\end{tabular}

Different letters superscript showed the significance in difference.

Table 4 Effect of certain additives on mean value of coliform count of served chicken and meat meals $(\mathrm{n}=24)$

\begin{tabular}{|c|c|c|c|c|c|c|}
\hline Additives & $\begin{array}{l}\text { Chicken } \\
\text { (before cooking) }\end{array}$ & $\begin{array}{l}\text { Chicken } \\
\text { (after cooking) }\end{array}$ & Red.\% & $\begin{array}{l}\text { Beef } \\
\text { (before cooking) }\end{array}$ & $\begin{array}{l}\text { Beef } \\
\text { (after cooking) }\end{array}$ & $\begin{array}{l}\text { Red. } \\
\%\end{array}$ \\
\hline Control & $9.5^{\mathrm{a}} \times 10 \pm 0.01 \times 10$ & $6^{\mathrm{bcd}} \times 10 \pm 0.01 \times 10$ & - & $1 \times 10^{2 \mathrm{a}} \pm 0.01 \times 10^{2}$ & $5.7^{\mathrm{c}} \times 10 \pm 0.01 \times 10$ & - \\
\hline $\mathrm{ACV}(2 \%)$ & $6.9^{\mathrm{bc}} \times 10 \pm 0.01 \times 10$ & $5.2^{\mathrm{cd}} \times 10 \pm 0.01 \times 10$ & 13.33 & $6.2^{\mathrm{c}} \times 10 \pm 0.01 \times 10^{2}$ & $4.2^{\mathrm{e}} \times 10 \pm 0.01 \times 10$ & 26.3 \\
\hline $\operatorname{ACV}(4 \%)$ & $4.3^{\text {ed }} \times 10 \pm 0.02 \times 10$ & $4.3^{\text {ed }} \times 10 \pm 0.02 \times 10$ & 28.33 & $3.3^{\mathrm{f}} \times 10 \pm 0.01 \times 10^{2}$ & $3.4^{\mathrm{f}} \times 10 \pm 0.01 \times 10$ & 40.4 \\
\hline $\mathrm{PM}(3 \%)$ & $7.5^{\mathrm{b}} \times 10 \pm 0.01 \times 10$ & $5.2^{\mathrm{cd}} \times 10 \pm 0.01 \times 10$ & 12.9 & $8.1^{b} \times 10 \pm 0.02 \times 10$ & $4.2^{\mathrm{e}} \times 10 \pm 0.02 \times 10$ & 26.3 \\
\hline $\mathrm{PM}(5 \%)$ & $5.2^{\mathrm{cd}} \times 10 \pm 0.01 \times 10$ & $4.2^{\mathrm{ed}} \times 10 \pm 0.01 \times 10$ & 30 & $5.2^{\mathrm{d}} \times 10 \pm 0.01 \times 10^{2}$ & $3.2^{\mathrm{f}} \times 10 \pm 0.01 \times 10$ & 43.9 \\
\hline $\operatorname{Mix}(2 \% \mathrm{ACV} \& 3 \% \mathrm{PM})$ & $2.7^{\mathrm{e}} \times 10 \pm 0.01 \times 10$ & $2.7^{\mathrm{e}} \times 10 \pm 0.01 \times 10$ & 55 & $2.6^{\mathrm{g}} \times 10 \pm 0.02 \times 10$ & $2.6^{\mathrm{g}} \times 10 \pm 0.01 \times 10$ & 54.4 \\
\hline
\end{tabular}

Different letters superscript showed significance differences $(\mathrm{p} \unlhd) .05$ ).

Table 5 Effect of certain additives on mean value of Staph. aureus count of served chicken and meat meals $(\mathrm{n}=24)$

\begin{tabular}{|c|c|c|c|c|c|c|}
\hline Additives & $\begin{array}{c}\text { Chicken } \\
\text { (before cooking) }\end{array}$ & $\begin{array}{l}\text { Chicken } \\
\text { (after cooking) }\end{array}$ & Red.\% & $\begin{array}{l}\text { Beef } \\
\text { (before cooking) }\end{array}$ & $\begin{array}{l}\text { Beef } \\
\text { (after cooking) }\end{array}$ & $\begin{array}{l}\text { Red. } \\
\%\end{array}$ \\
\hline Control & $9.9^{\mathrm{a}} \times 10 \pm 0.01 \times 10$ & $9.9^{\mathrm{a}} \times 10 \pm 0.01 \times 10$ & - & $8.6^{\mathrm{ab}} \times 10 \pm 0.02 \times 10$ & $8.6^{\mathrm{ab}} \times 10 \pm 0.02 \times 10$ & - \\
\hline $\operatorname{ACV}(2 \%)$ & $9.8^{\mathrm{a}} \times 10 \pm 0.02 \times 10$ & $8.7^{\mathrm{ab}} \times 10 \pm 0.02 \times 10$ & 12 & $9.4^{\mathrm{a}} \times 10 \pm 0.02 \times 10$ & $7.7^{\mathrm{c}} \times 10 \pm 0.02 \times 10$ & 10.5 \\
\hline $\operatorname{ACV}(4 \%)$ & $8.7^{\mathrm{a}} \times 10 \pm 0.01 \times 10$ & $8.7^{\mathrm{a}} \times 10 \pm 0.01 \times 10$ & 12 & $8^{\mathrm{bc}} \times 10 \pm 0.02 \times 10$ & $7.7^{\mathrm{c}} \times 10 \pm 0.02 \times 10$ & 10.5 \\
\hline $\operatorname{PM}(3 \%)$ & $5.7^{\mathrm{b}} \times 10 \pm 0.02 \times 10$ & $9.3^{\mathrm{a}} \times 10 \pm 0.02 \times 10$ & 6 & $8.3^{b} \times 10 \pm 0.01 \times 10$ & $8.6^{\mathrm{ab}} \times 10 \pm 0.01 \times 10$ & - \\
\hline $\mathrm{PM}(5 \%)$ & $4.2^{\mathrm{c}} \times 10 \pm 0.01 \times 10$ & $3.1^{\mathrm{cd}} \times 10 \pm 0.01 \times 10$ & 68.7 & $6.2^{\mathrm{d}} \times 10 \pm 0.01 \times 10$ & $4.2 \times 10 \pm 0.01 \times 10$ & 51 \\
\hline $\operatorname{Mix}(2 \% \mathrm{ACV} \& 3 \% \mathrm{PM})$ & $3.7^{\mathrm{cd}} \times 10 \pm 0.02 \times 10$ & $2.8^{\mathrm{d}} \times 10 \pm 0.02 \times 10$ & 71.7 & $4.2^{\mathrm{c}} \times 10 \pm 0.01 \times 10$ & $3.2^{\mathrm{f}} \times 10 \pm 0.01 \times 10$ & 62.8 \\
\hline
\end{tabular}

Different letters superscript showed significance differences $(\mathrm{p} \triangle(0.05)$.

\section{DISCUSSION}

Sensory profile allows us to evaluate the quality of food and in some time to identify unwanted contaminants (Rasooli, 2007). It is obvious from results obtained in Table (1) that the sensory properties in different marinated groups were enhanced by addition of pomegranate molasses and apple cider vinegar.

Bacteriological profile: It is evident from the result recorded in Table (2-4) that apple cider vinegar (ACV) and pomegranate molasses (PM) were positively affect mean values of APC, Enterobacteriacae and Coliform in examined samples of both chicken and beef meals and the best results were obtained by group that marinated with mixture $\mathrm{ACV}(2 \%) \& \mathrm{PM}(3 \%)$ followed by that marinated with $4 \% \mathrm{ACV}$ and that marinated with $\mathrm{PM}(5 \%)$ and there is a significant difference between all groups $(\mathrm{P} \unlhd) .05)$. The highest reduction percentage in bacterial count of APC, Enterobacteriacae, Coliform were in the groups that marinated with mixture of $\mathrm{ACV}(2 \%) \& \mathrm{PM}(3 \%)$ followed by ACV (4\%) and PM (5\%).

Bige et al. (2010) said that Pomegranate molasses is a highly nutritive product since it is processed as concentrate. Especially the presence of high mineral contents of the fruit are in higher concentration of the molasses, makes it an exceptional nutritional property and it was found that to 
have a good antioxidant activity an important aspect important for human health.

Many studies assured the antibacterial effect of pomegranate products as Vaithiyanathan et al. (2011) who said that when raw chicken breasts are dipped in $0.02 \%$ pomegranate fruit juice this can reduce oxidation, inhibit growth of bacteria and increase sensory acceptability, Kanatt et al. (2010) also suggested that the addition of pomegranate extract on poultry products enhanced its shelf life. The results of several studies showed that pomegranate products had an antimicrobial effect on several bacteria including pathogens. The antimicrobial spectrum changed depending on the product type and the test microorganism. Apple cider vinegar has antibacterial effect because it contains organic acids as reported by Budak et al. (2011). Also, Saquib (2017) reported that ACV exhibited potent antibacterial activity against Gram positive and Gramnegative bacterial strains.

Table (5) showed apple cider vinegar and pomegranate molasses effect with different concentrations on incidence of Staph. aureus in examined samples, as shown the highest red.\% was obtained by the mixture of $\operatorname{ACV}(2 \%)+\mathrm{PM}(3 \%)$ followed by $\mathrm{PM}(5 \%)$.

Addition of pomegranate molasses positively affects Staph. aureus resulting in dramatically reduction in its count. These agree with Malviya et al., (2014) who studied antibacterial activity of pomegranate peel extracts and found that the maximum was against Staph. aureus. Also, Tayel et al. (2012) reported that decontamination of meat surfaces can be achieved by addition of pomegranate extracts. Moreover, Kanatt et al. (2010) who studied the antibacterial\& antioxidant properties of pomegranate extract which showed a noticed antibacterial effect to $S$. aureus. Generally, it is recommended that these natural components should be incorporated in our food not only due to their antimicrobial effect but also to enhance the nutritive value of food to achieve healthy food.

\section{CONCULSION}

In conclusion, Sensory attributes of different treated chicken and beef samples were mostly improved with all treatments when compared with control. The best effectiveness of reduction of bacterial and pathogen contamination was given by mixture of ACV $(2 \%)+\mathrm{PM}$ (3\%) followed by PM (5\%) in comparison with all groups specially control.

\section{REFERENCES}

1. American public Health Association "APHA" (2001): compendium of methods for the microbiological examination of food $4^{\text {th }}$ Ed. Aquafind.com/articles/Value Added -fishprocess.php.

2. Bige, .; Canan E. T.; Ömer U. Ç. (2010): A Research on the Composition of Pomegranate Molasses. Journal of Agricultural Faculty of Uludag University, Vol. 24 (2): $37-$ 47.

3. Budak, N. H. ; Kumbul Doguc, D. ; Savas, C. M. ; Seydim, A. C. ; Kok Tas, T. ; Ciris, M. I. and Guzel-Seydim, Z. B (2011): Effects of apple cider vinegars produced with different techniques on blood lipids in high-cholesterol-fed rats. J. Agric. Food Chem., 59/12 6638-6644.

4. Feldman, D.; Ganon, J.; Haffman, R. and Simpson, J. (2003): The solution for data analysis and presentation graphics. 2 nd Ed., Abacus Lancripts, Inc., Berkeley, USA.

5. Food Safety and Inspection service "FSIS" (2008): United States Department of Agriculture: FSIS Issues public Health Alter for Frozen, Stuffed Raw chicken product.

6. International Commission and Microbiological Specification for Food "ICMSF" ( 1996): Microorganism in foods 1.Their significance and methods of enumeration. 3rd Ed Toronto, Univ. of Toronto press.

7. International Commission and Microbiological Specification for Food "ICMSF" (1997): Microorganism in foods, Microbial ecology of food commodities.2nd ed. Klumer Academics, plenum publishers. London, U.K.

8. International Organization of Standardization 'ISO' (2001): No.1129-1.Microbiology of food and animal feeding stuffsHorizontal methods for detection and enumeration of Bglucosidase-positive Escherichia coli. part2 ; colony count technique at $44^{\circ} \mathrm{c}$ using 5 bromo-4-chloro-3-indolyl B-Dglucuronide.

9. International Organization of Standerdization6579 "ISO (2002): $4^{\text {th }}$ Ed. Microbiology- General Guidance on methods for the detection of salmonella, International Organization for Standardization, Geneva, Switzerland.

10. International Organization of Standardization 'ISO' (2004): No.1129-1.Microbiology of food and animal feeding stuffsHorizontal methods for detection and enumeration of Enterobacteriacae part 2 ; ; colony count method.

11. Kalaba, V.; Balaban, Z.M. and Kalaba, D.(2019): Antibacterial activity of domestic apple cider vinegar. AGR. Int. J., Vol. 4, Issue No. 1.

12. Kanatt, S.R.; Chander, R. and Sharma, A. (2010): Antioxidant and antimicrobial activity of pomegranate peel extract improves the shelf life of chicken products. Intl J Food Sci Technol 45: 216-22.

13. Malviya, S.; Jha, A.A.; Hetiarachchy, N. (2014): Antioxidant and antibacterial potential of pomegranate peel extract. JFST51 51(12): 4132-4137.16.

14. Meilgaard, M. C. ; Carr, T. and Civille, G. (Eds.) (1999): Sensory evaluation techniques. CRC Press Inc.

15. Rani, P. and Khullar, N. (2004): "Antimicrobial evaluation of some medicinal plants for their anti-enteric potential against multi-drug resistant Salmonella typhi," Phytotherapy Research, vol. 18 , no. 8, pp. 670-673.

16. Rasooli, I. (2007): Food preservation-A biopreservative approach. Global Science Books, Food, 1: 111-136.

17. Saquib,A .(2017): Antimicrobial Activity of Apple Cider Vinegar. Mapana Journal of sciences, Vol.16, No.2, 11-15.

18. Sharp, K. and Walker, H. (2003): A microbiological survey of communal kitchens used by under graduated students. International journal of Consumer studies, 27(1):11-16.

19. Tayel, A.; El-Tras, W.; Moussa, S. and El-Sabbagh, S. (2012): "Surface decontamination and quality enhancement in meat steaks using plant extracts as natural biopreservatives," Foodborne Pathogens and Disease, 9 (8): 755-761.

20. Vaithiyanathan, S.; Naveena, B. M.; Muthukumar, M.; Girish, P. S. and Kondaiah, N. (2011): "Effect of dipping in pomegranate (Punica granatum) fruit juice phenolic solution on the shelf life of chicken meat under refrigerated storage $\left(4^{\circ} \mathrm{C}\right)$," Meat Science, vol. 88, no. 3, pp. 409-414.

21. Zeweifel, C.; Baltzer, D. and Stephan, R., (2005) Microbiological contamination of cattle carcasses at five abattoirs determined by swab sampling in accordance with EU. Decision 2001/471/EC. J. Meat Sci., 69:559-566. 